\title{
Viral haemorrhagic septicaemia virus (VHSV Id) infections are detected more consistently using syndromic vs. active surveillance
}

\author{
Pia Vennerström ${ }^{1, *}$, Elina Välimäki ${ }^{1}$, Tapani Lyytikäinen ${ }^{2}$, Maria Hautaniemi ${ }^{3}$, \\ Gabriele Vidgren ${ }^{1}$, Perttu Koski ${ }^{4}$, Anna-Maija Virtala ${ }^{5}$
}

\author{
${ }^{1}$ Veterinary Bacteriology and Pathology Research Unit, Finnish Food Safety Authority, 00790 Helsinki, Finland \\ ${ }^{2}$ Risk Assessment Research Unit, Finnish Food Safety Authority, 00790 Helsinki, Finland \\ ${ }^{3}$ Virology Research Unit, Finnish Food Safety Authority, 00790 Helsinki, Finland \\ ${ }^{4}$ Veterinary Bacteriology and Pathology Research Unit, Finnish Food Safety Authority, 90590 Oulu, Finland \\ ${ }^{5}$ Department of Veterinary Biosciences, Faculty of Veterinary Medicine, University of Helsinki, 00014 University of Helsinki, Finland
}

\begin{abstract}
The eradication of viral haemorrhagic septicaemia virus (VHSV Id) from Finnish brackish-water rainbow trout Oncorhynchus mykiss farms located in the restriction zone in the Province of Åland, Baltic Sea, failed several times in the 2000s. The official surveillance programme was often unable to find VHSV-positive populations, leading to the misbelief in the fish farming industry that virus eradication could be achieved. The ability of 3 other surveillance programmes to detect infected fish populations was compared with the official programme. One programme involved syndromic surveillance based on the observation of clinical disease signs by fish farmers, while 2 programmes comprised active surveillance similar to the official programme, but included increased sampling frequencies and 2 additional tests. The syndromic surveillance concentrated on sending in samples for analysis when any sign of a possible infectious disease at water temperatures below $15^{\circ} \mathrm{C}$ was noticed. This programme clearly outperformed active surveillance. A realtime reverse transcriptase-polymerase chain reaction method proved to be at least as sensitive as virus isolation in cell culture in detecting acute VHSV infections. An ELISA method was used to test fish serum for antibodies against VHSV. The ELISA method may be a useful tool in VHSV eradication for screening populations during the follow-up period, before declaring an area free of infection.
\end{abstract}

KEY WORDS: Rainbow trout $\cdot$ Oncorhynchus mykiss $\cdot$ Novirhabdovirus $\cdot$ Rhabdoviridae $\cdot$ Virus eradication $\cdot$ Fish farm $\cdot$ Aquaculture $\cdot$ RT-PCR $\cdot$ ELISA $\cdot$ Finland

\section{INTRODUCTION}

Viral haemorrhagic septicaemia (VHS) is a fish disease that has been described in more than 80 fish species in both fresh and marine waters (review by Skall et al. 2005a, Elsayed et al. 2006, Lumsden et al. 2007, Dale et al. 2009, Bain et al. 2010, Gadd et al. 2010, 2011, Kim \& Faisal 2010, Emmenegger et al. 2013, Ito \& Olesen 2013). The disease is caused by VHS virus (VHSV), a virus belonging to the genus

${ }^{*}$ Corresponding author: pia.vennerstrom@evira.fi
Novirhabdovirus of the family Rhabdoviridae (Walker et al. 2000). VHSV is a single-stranded enveloped RNA virus that is divided into 4 genotypes (I-IV), of which I and IV have several sublineages (Ia-Ie, IVa-IVc) (Snow et al. 1999, Einer-Jensen et al. 2005, Elsayed et al. 2006, Ammayappan \& Vakharia 2009, Pierce \& Stepien 2012). The susceptibility to different VHSV genotypes varies among fish species (Skall et al. 2005b, Schönherz et al. 2013). In aquaculture, VHS is a severe infectious disease of farmed rainbow

(C) The authors 2017. Open Access under Creative Commons by Attribution Licence. Use, distribution and reproduction are unrestricted. Authors and original publication must be credited. 
trout Oncorhynchus mykiss, turbot Scophthalmus maximus and Japanese flounder Paralichthys olivaceus (Ross et al. 1995, Smail 1999, Isshiki et al. 2001). Infections caused by VHSV genotype I are among the most serious viral diseases in rainbow trout farming, causing mortalities of up to $80-100 \%$ in rainbow trout fry and 10-50\% in fingerlings and older fish (Smail 1999). Due to its ability to cause severe disease in wild and cultured fish, VHSV is a notifiable disease to the World Organisation of Animal Health (OIE 2017). In North America, high mortalities have also been reported in several wild fish species infected with VHSV genotype IV (Meyers et al. 1999, Hedrick et al. 2003, Groocock et al. 2007, Lumsden et al. 2007, Garver et al. 2013).

In Finland, VHS was diagnosed for the first time in spring 2000 at a fish farm producing rainbow trout for consumption in open net pens in the sea area of the Province of Åland (hereafter called Åland; Fig. 1), and almost at the same time at a similar fish farm on the south coast of continental Finland approximately $330 \mathrm{~km}$ away (Raja-Halli et al. 2006). Infection with VHSV genotype Id spread rapidly between fish farms in Åland, despite extensive eradicative measures, and in 2001, a restriction zone including the whole province was established. Movement of live fish, ungutted farmed fish and fish farming equipment including well boats from the restriction area was forbidden. However, eradicative measures were successful in the second area on the south coast, and VHSV has not been isolated there since 2001. In 2003, VHSV spread from Åland to a third area, a fish farm also producing rainbow trout on the west coast of continental Finland (Raja-Halli et al. 2006). Infection was successfully eradicated in the same year and VHSV was not reported until 2008, when the virus was isolated again. Eradication was repeated and no infection has been recorded since 2008.

The disease situation in the restriction zone of Åland was screened according to official EU protocols and tests (2001/183/EC and 2003/634/EC; EC 2001, 2003). New disease outbreaks were often reported 1-2 wk after fish from a VHS-free area were moved to sites that had been empty of fish for 8$12 \mathrm{mo}$, including the removal and disinfection of all farming equipment (later fallowed).

The fish farming industry in Åland started to improve biosecurity on farms, but willingness to change the infrastructure to a higher biosecurity standard was low, as wild fish were believed to be the source of reinfections. Initial phylogenetic reports of the Finnish farm isolates hypothesized that wild fish populations were the source of the primary infection
(Raja-Halli et al. 2006). Nevertheless, surveillance efforts that screened wild herring, sprat, salmonid brood fish and lampreys Lampetra fluviatilis for VHSV between 2004 and 2006 on the west coast of Finland in the Baltic Sea, remained negative for VHSV Id (Gadd et al. 2010, 2011). Furthermore, subsequent screening of wild fish in the vicinity of the study farms reported on herein also suggested a lack of VHSV in wild fish (P. Vennerstöm unpubl. data). Recurrent outbreaks of VHS in Åland were difficult to explain, and suspicion about the surveillance programme was raised, including the diagnostic sensitivity in screening for the presence of VHSV infection. It was suspected that the surveillance programme and methods used were only able to find the 'tip of the iceberg' and that in order to achieve successful eradication, surveillance activities needed to be improved.

Here, we report the first part of a set of epidemiologic studies performed during 2006-2009 in the VHS restriction area of Alland, where VHSV was suspected to be present. More information on the presence of infection was needed to plan eradication measures. The aim was to compare 4 sampling strategies, later called programmes, to detect VHSV-infected fish in fish populations reared by 2 fish farming companies. Two diagnostic tests, a real-time reverse transcriptase-polymerase chain reaction (qRT-PCR) for

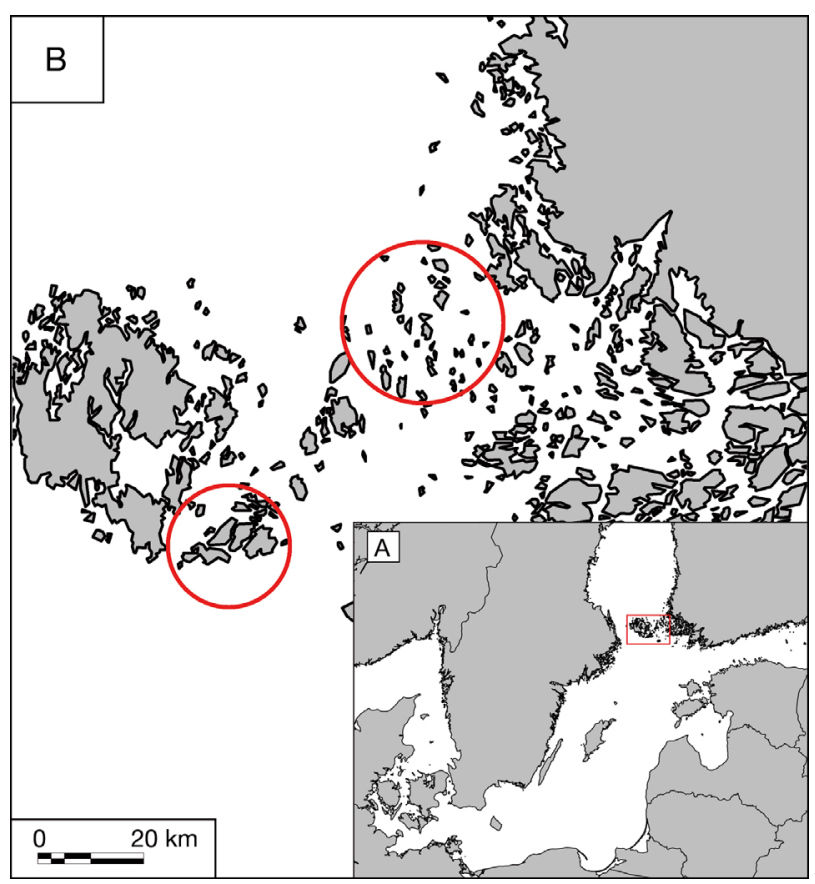

Fig. 1. (A) Geographical location of the Province of Åland (red rectangle), which is the viral haemorrhagic septicaemia restriction zone. (B) Study areas (circles) within the restriction zone 
detecting viral nucleic acid from organ samples and an ELISA test for the presence of antibodies against VHSV in fish serum, were compared with the official EU tests, namely virus isolation by cell culture combined with an antigen detection ELISA, which is considered the reference method (OIE 2017). Another aim was to test whether syndromic surveillance by the staff on the farms would provide enough information to plan the eradication of VHS.

\section{MATERIALS AND METHODS}

\section{Description of fish farms and populations selected for surveillance and the study area}

Two companies (A and B) from a VHS restriction zone in Aland (Fig. 1) that used open net pens at sea to produce rainbow trout for consumption were screened for the presence of VHSV in their fish populations. In this study, a population included fish of the same origin and age, even if they were farmed at the same site with fish of other origins and ages. Company A had 2 farming sites, A1 and A2. A1 was constantly populated, but site A2 was only used during summer when the water temperatures had risen. A2 was situated further offshore than A1 and was populated with fish intended to be slaughtered in the following autumn or winter. Company A constantly had several fish populations present (AP1, 2, 3, ...), and the number of populations site $^{-1}$ depended on the time of year. Sites A1 and A2 were considered as 1 epidemiological unit, as they were situated $<1 \mathrm{~km}$ apart, had the same staff taking care of daily services, and the populations were circulated between these 2 sites. Company B had 15 farming sites, most of which were summer farming sites that were followed during the winter. These farming sites were further apart from each other than those in Company A, but were also populated with several populations circulating between different sites. The fish of both companies were transported from a VHS-free zone in continental Finland. Company A imported some of its populations from abroad from a VHS-free zone in Denmark (author's unpubl. data). In addition, the domestic fish populations in the study were examined by virus isolation in cell culture and found negative for the presence of VHSV before transportation to the selected farms. The foreign fish were sampled before they were placed in the net pens. In our experience, VHSV Id cannot be isolated at water temperatures $>15^{\circ} \mathrm{C}$. In the study area, this temperature was measured from late June to September-October in 2006-2008. All farm visits and sampling were performed when the water temperature was $\leq 15^{\circ} \mathrm{C}$, except for 1 case in Programme 2, when the population arrived at the farm in June 2006 (see Tables 1 \& 2). From December-January to early May, the water temperature was $<5^{\circ} \mathrm{C}$ (in total, 18-24 wk annually) (Lehtiniemi \& Lehtinen 2016). The salinity in the study area was ca. 5.4-6.0\%.

\section{Surveillance programmes, times and sampling}

All populations (P) in Companies $\mathrm{A}$ and $\mathrm{B}$ at a total of 17 separate farming sites (AP1-2, BP1-BP15) were observed by 4 simultaneous surveillance programmes, 1-4, during 3 yr, 2006-2008. The sampling schedule, collected samples, sites from where the populations were sampled and the tests used are summarized in Table 1 and described in more detail below and in Table 2 .

Programme 1 was conducted from May 2006 to the end of 2008 and consisted of syndromic surveillance performed by the staff of the fish farms. As soon as any signs of a possible disease outbreak were detected, the staff, consisting of several persons, had been instructed to send 5-10 euthanized whole fish to the laboratory for autopsy and sampling. VHS outbreaks in Finland have not been reported at water temperatures above $15^{\circ} \mathrm{C}$, and only samples taken

Table 1. Code of action in different surveillance programmes. Water temperature was $<15^{\circ} \mathrm{C}$ on all sampling occasions

\begin{tabular}{|c|c|c|c|c|c|c|c|}
\hline \multirow{3}{*}{ No. } & \multirow{3}{*}{$\begin{array}{l}\text { - Programme } \\
\text { Description }\end{array}$} & \multirow[t]{3}{*}{ Sampling frequency } & \multirow{3}{*}{$\begin{array}{l}\text { Diseased } \\
\text { fish }\end{array}$} & \multirow{3}{*}{$\begin{array}{c}\text { Fish } \\
\text { sampled }\end{array}$} & \multirow{2}{*}{\multicolumn{2}{|c|}{$\begin{array}{l}\text { Number per sampling occasior } \\
\text { Pooled samples }\end{array}$}} & \multirow{3}{*}{$\begin{array}{l}\text { Serum } \\
\text { samples }\end{array}$} \\
\hline & & & & & & & \\
\hline & & & & & Virus isolation & qRT-PCR & \\
\hline 1 & Syndromic & $\begin{array}{l}\text { Always if mortality elevated or } \\
\text { signs of disease present }\end{array}$ & Always & $1-10$ & $1-5$ & $1-5$ & 0 \\
\hline 2 & Active, random & Once every spring and autumn & If noticed & 30 & 6 & 6 & 30 \\
\hline 3 & Active, non-random & Once every spring and autumn & If noticed & 30 & 6 & 6 & 30 \\
\hline 4 & EU reference & $\begin{array}{l}\text { Once a year in uninfected farms; } \\
\text { every } 2 \text { nd year in infected farms }\end{array}$ & If noticed & 30 & 3 & 3 & 0 \\
\hline
\end{tabular}


Table 2. Results of surveillance for viral haemorrhagic septicaemia virus (VHSV) of fish populations during 2006-2008. In Programme 1, farmers from companies A and B performed syndromic surveillance and collected the tested samples. In the active surveillance of Programme 2, fish populations were randomly selected from Companies A and B. In the active surveillance of Programme 3, VHS-positive fish populations were non-randomly selected during 2007 and 2008 from Company B. In Programme 4, official EU surveillance of farms A and B was conducted by the competent authority according to Commission Decisions 2001/183/EC and 2003/634/EC (EC 2001, 2003). N: number; A: Company A; B: Company B; the number indicates the farming site of the company; P refers to population and the numbers indicate different populations; nd: not done and not included in statistical comparison of virus isolation and real-time (q)RT-PCR tests; na: not applicable to that programme; A.s.: Aeromonas salmonicida sp. salmonicida bacterial infection; PKD: proliferative kidney disease; RTFS: rainbow trout fry syndrome; Y.r.: Yersinia ruckeri bacterial infection; IPN: infectious pancreas necrosis; -: no information

\begin{tabular}{|c|c|c|c|c|c|c|c|c|c|}
\hline $\begin{array}{l}\text { Sampled } \\
\text { sites }\end{array}$ & $\begin{array}{c}\text { Population } \\
\text { ID }\end{array}$ & $\begin{array}{l}\text { Sampling } \\
\text { date }\end{array}$ & $\begin{array}{l}\text { Temp. } \\
\left({ }^{\circ} \mathrm{C}\right)\end{array}$ & $\begin{array}{l}\text { Clinical } \\
\text { signs }\end{array}$ & $\begin{array}{c}\mathrm{N} \text { fish } \\
\text { sampled (N } \\
\text { organ pools) }\end{array}$ & $\begin{array}{l}\text { N positive } \\
\text { Virus } \\
\text { isolation }\end{array}$ & $\begin{array}{l}\text { organ pools } \\
\text { qRT-PCR }\end{array}$ & $\begin{array}{c}\text { N seropositive } \\
\text { fish ELISA+ } \\
\text { ( } \mathrm{N} \text { tested fish) }\end{array}$ & Diagnosis \\
\hline \multicolumn{10}{|c|}{ Programme 1} \\
\hline A1 & AP1 & May 2006 & 11 & Yes & $9(9)$ & 9 & nd & na & VHS \\
\hline A1 & AP2 & Sep 2006 & 15 & Yes & $4(4)$ & 0 & 0 & na & A.s., PKD \\
\hline A1 & AP2 & Apr 2007 & 3 & Yes & $6(4)$ & 0 & 0 & na & RTFS \\
\hline A1 & AP4 & Apr 2008 & 4 & Yes & $3(3)$ & 3 & 3 & na & VHS \\
\hline A1 & AP4 & May 2008 & 7 & Yes & $4(4)$ & 4 & 4 & na & VHS \\
\hline A1 & AP4 & May 2008 & 7 & Yes & $4(4)$ & 4 & 4 & na & VHS \\
\hline A1 & AP5 & Sep 2007 & 13 & Yes & $14(2)$ & 0 & 0 & na & Y.r. \\
\hline A1 & AP5 & Mar 2008 & 2 & Yes & $5(5)$ & 5 & 5 & na & VHS \\
\hline B5 & BP1 & Jun 2006 & 12 & Yes & $10(2)$ & 2 & nd & na & VHS \\
\hline B6 & BP6 & May 2008 & 10 & Yes & $1(1)$ & 1 & nd & na & VHS \\
\hline B4 & BP7 & Jun 2007 & 12 & Yes & $10(2)$ & 2 & 2 & na & VHS, RTFS \\
\hline B4 & BP7 & Nov 2007 & 6 & Yes & $2(2)$ & 2 & 2 & na & VHS \\
\hline Total & & & & 12 & $72(42)$ & 32 & 20 & & \\
\hline \multicolumn{10}{|c|}{ Programme 2} \\
\hline A1 & AP2 & Jun 2006 & 18 & No & $60(6)$ & 0 & 0 & nd & IPN \\
\hline A1 & AP2 & Jan 2007 & 4 & No & $30(6)$ & 0 & 0 & $0(15)$ & Negative \\
\hline A1 & AP2 & Apr 2007 & 7 & No & $30(6)$ & 0 & 0 & 0 (15) & Negative \\
\hline A1 & AP2 & Jun 2007 & 13 & Yes & $30(6)$ & 0 & 0 & nd & Y.r. \\
\hline A1 & AP2 & Nov 2007 & 7 & No & $30(6)$ & 0 & 0 & $0(15)$ & Negative \\
\hline B6 & BP2 & Dec 2006 & 5 & No & $30(6)$ & 0 & 0 & 1 (15) & Negative \\
\hline B9 & BP2 & Jun 2007 & 12 & No & $30(6)$ & 0 & 0 & nd & Negative \\
\hline B6 & BP2 & Oct 2007 & 10 & No & $30(6)$ & 0 & 0 & $2(15)$ & Negative \\
\hline B5 & BP3 & Dec 2006 & 5 & No & $30(6)$ & 0 & 0 & $0(15)$ & Negative \\
\hline B5 & BP3 & Jun 2007 & 12 & No & $30(6)$ & 0 & 1 & 0 (15) & VHS \\
\hline B3 & BP3 & Dec 2007 & 6 & Yes & $30(6)$ & 4 & 4 & 1 (15) & VHS \\
\hline Total & & & & 2 & $360(66)$ & 4 & 5 & $4(120)$ & \\
\hline \multicolumn{10}{|c|}{ Programme 3} \\
\hline B7 & BP4 & Jun 2007 & 13 & Yes & $15(15)$ & 2 & 2 & nd & VHS \\
\hline B7 & BP4 & Jul 2007 & 15 & No & $30(6)$ & 0 & 0 & $8(30)$ & Negative \\
\hline B6 & BP4 & Nov 2007 & 7 & No & $30(6)$ & 0 & 0 & 19 (30) & Negative \\
\hline B6 & BP4 & May 2008 & 6 & No & $30(6)$ & 3 & 3 & $8(30)$ & VHS \\
\hline B10 & BP4 & Oct 2008 & 12 & No & $30(6)$ & 0 & 0 & nd & Negative \\
\hline B7 & BP4E & Jul 2007 & 15 & No & $30(6)$ & 0 & 0 & $21(30)$ & Negative \\
\hline B6 & BP4E & Nov 2007 & 7 & No & $30(6)$ & 0 & 0 & $16(30)$ & IPN \\
\hline B6 & BP4E & May 2008 & 6 & Yes & $30(6)$ & 1 & 1 & $1(30)$ & VHS \\
\hline B10 & BP4E & Oct 2008 & 12 & No & $30(6)$ & 0 & 0 & nd & Negative \\
\hline B8 & BP5 & Jun 2007 & 12 & Yes & $30(6)$ & 3 & 3 & $8(30)$ & VHS, RTFS \\
\hline B8 & BP5 & Jul 2007 & 15 & No & $30(6)$ & 0 & 0 & $25(30)$ & Negative \\
\hline B8 & BP5 & Nov 2007 & 6 & No & $242(48)$ & 0 & 0 & 14 (30) & Negative \\
\hline B8 & BP5E & Jul 2007 & 15 & No & $30(6)$ & 0 & 0 & $25(30)$ & Negative \\
\hline B8 & BP5E & Dec 2007 & 6 & Yes & $200(40)$ & 1 & 1 & $2(20)$ & VHS \\
\hline Total & & & & 4 & 772 (169) & 10 & 10 & $147(350)$ & \\
\hline \multicolumn{10}{|c|}{ Programme 4} \\
\hline B12 & & Nov 2006 & 5 & No & $30(3)$ & 0 & na & na & Negative \\
\hline B4 & & Nov 2006 & 5 & No & $30(3)$ & 0 & na & na & Negative \\
\hline B8 & & Nov 2006 & 5 & No & $20(2)$ & 0 & na & na & Negative \\
\hline B14 & & Nov 2006 & 5 & No & $30(3)$ & 0 & na & na & Negative \\
\hline
\end{tabular}


Table 2. (continued)

\begin{tabular}{|c|c|c|c|c|c|c|c|c|c|}
\hline $\begin{array}{l}\text { Sampled } \\
\text { sites }\end{array}$ & $\begin{array}{c}\text { Population } \\
\text { ID }\end{array}$ & $\begin{array}{l}\text { Sampling } \\
\text { date }\end{array}$ & $\begin{array}{l}\text { Temp. } \\
\left({ }^{\circ} \mathrm{C}\right)\end{array}$ & $\begin{array}{c}\text { Clinical } \\
\text { signs }\end{array}$ & $\begin{array}{c}\mathrm{N} \text { fish } \\
\text { sampled ( } \mathrm{N} \\
\text { organ pools) }\end{array}$ & $\begin{array}{c}\text { N positive } \\
\text { Virus } \\
\text { isolation }\end{array}$ & $\begin{array}{c}\text { organ pools } \\
\text { qRT-PCR }\end{array}$ & $\begin{array}{c}\mathrm{N} \text { seropositive } \\
\text { fish ELISA+ } \\
\text { ( } \mathrm{N} \text { tested fish) }\end{array}$ & Diagnosis \\
\hline B15 & & May 2007 & 8 & No & $30(3)$ & 0 & na & na & IPN \\
\hline A1 & & Jun 2007 & 13 & No & $30(3)$ & 0 & na & na & Negative \\
\hline A1 & & Jun 2007 & 13 & Yes & $27(2)$ & 0 & na & na & IPN, Y.r. \\
\hline B9 & & Jun 2007 & 13 & No & $30(3)$ & 0 & na & na & Negative \\
\hline B5 & & Jun 2007 & 13 & No & $30(3)$ & 0 & na & na & Negative \\
\hline B1 & & Jun 2007 & 13 & No & $30(3)$ & 0 & na & na & Negative \\
\hline B12 & & Oct 2007 & 10 & No & $30(3)$ & 0 & na & na & Negative \\
\hline B13 & & Oct 2007 & 10 & No & $30(3)$ & 0 & na & na & Negative \\
\hline B14 & & Dec 2007 & 4 & No & $30(3)$ & 0 & na & na & Negative \\
\hline B14 & & Jun 2008 & 11 & No & $20(3)$ & 0 & na & na & Negative \\
\hline B5 & & Jun 2008 & 15 & No & $30(3)$ & 0 & na & na & Negative \\
\hline B12 & & Jun 2008 & 15 & No & $30(3)$ & 0 & na & na & Negative \\
\hline B13 & & Jun 2008 & 15 & No & $30(3)$ & 0 & na & na & Negative \\
\hline B15 & & Jun 2008 & 15 & No & $30(3)$ & 0 & na & na & Negative \\
\hline B11 & & Oct 2008 & 8 & - & $30(3)$ & 1 & na & na & VHS \\
\hline B9 & & Oct 2008 & 8 & No & $2(1)$ & 0 & na & na & Negative \\
\hline B12 & & Oct 2008 & 8 & Yes & $30(3)$ & 0 & na & na & Negative \\
\hline B12 & & Oct 2008 & 8 & Yes & $30(3)$ & 0 & na & na & Negative \\
\hline A1 & & Dec 2008 & 5 & Yes & $9(3)$ & 0 & na & na & PKD \\
\hline Total & & & & 5 & $618(65)$ & 1 & & & \\
\hline
\end{tabular}

below this temperature were included in this study. VHS-diseased fish are often lethargic and dark in colour, with varying degrees of exophthalmia. Typical signs in the acute phase of the disease are widespread petechial haemorrhage, which can be seen throughout the internal organs, serosa, muscle tissue and eyes. In survivors, a chronic form of the disease may be seen when haemorrhaging is reduced, but anaemia may be severe. Swimming with an erratic and corkscrewing motion (termed 'flashing'), including surface swimming on some occasions, indicates a nervous stage of the disease (Smail \& Snow 2011). There are no pathognomonic signs for VHS, and similar signs may also be seen in other infectious fish diseases. Therefore, the farmers were instructed to send in samples throughout the year. During the surveillance period $\left(<15^{\circ} \mathrm{C}\right)$, the fish farmers sent in samples for autopsy 12 times from a total of 72 fish, which were combined into 42 organ pools (Table 2). No blood samples were collected from these fish.

Programme 2 was an active targeted surveillance programme focused on a population (AP2) from Company A and 2 populations (BP2 and BP3) from 2 farming sites (B6 and B5) of Company B. VHS disease had previously occurred at all of these farming sites, but only Company B was able to fallow its sites before surveillance started. The sample size was at least 30 fish population ${ }^{-1}$ on each sampling occasion, according to the official EU protocols 2001/183/EC and 2003/634/EC (EC 2001, 2003). Fish with clinical signs such as lethargy, dark skin, exophthalmia and erratic swimming indicating possible VHSV infection were first selected for sampling, and the rest were caught with a dip net. The fish were euthanized after capture, and individual blood samples were immediately collected from the caudal vein. The surveillance of AP2 started in June 2006, when the fish populations arrived from Denmark. The final samples were collected when the population was slaughtered during the winter of 2007. The surveillance of BP2 and BP3 started in December 2006, when the populations arrived from the VHS-free zone of continental Finland, and ended when the populations were slaughtered in December 2007. In Programme 2, the 3 selected populations (AP2, BP2 and BP3) were sampled 11 times altogether, and 360 fish were pooled into 66 organ samples (Table 2).

Programme 3 was also an active targeted surveillance programme. Two populations (BP4 and BP5) were selected from 2 fallowed farming sites (B7 and B8) of Company B immediately after a clinical VHS outbreak was diagnosed in these populations in June 2007. From these 2 farming sites, the fish populations next to the diseased populations BP4 and BP5 were also selected for surveillance. These 2 new populations, BP4E and BP5E, had no visible clinical signs of VHSV infection, but were potentially naturally exposed (E) to the virus. The surveillance started in June 2007 and ceased when the fish were slaughtered at the end of 2007 and 2008. Sampling was per- 
formed as in Programme 2, with the exception that the first sample from BP4 included only 15 fish that were individually tested and the last samples from BP5 and BP5E included at least 200 fish. The VHSVpositive population BP4 and the neighbouring population, BP4E, were sampled 4 times after the first outbreak of clinical VHS in June 2007. Follow-up samples were taken in July 2007, November 2007, May 2008 and October 2008 from a total of 255 fish pooled into 63 organ pools (Table 2). The second VHSV-positive population, BP5, and its neighbouring population, BP5E, were sampled twice after the first outbreak of clinical VHS in June 2007, with 532 fish pooled into 106 organ pools (Table 2). Control fish of the same origin as BP4, BP4E, BP5 and BP5E were also tested. They were situated outside the VHS restriction zone.

Programme 4 comprised surveillance according to official EU protocols 2001/183/EC and 2003/634/EC (EC 2001, 2003), and was conducted at all farming sites of Companies A and B. The EU protocol requires that fallowed farming sites or sites where VHS has never been recorded are inspected twice a year and sampled once a year. VHS-positive farming sites were inspected once a year and sampled every second year during 2006-2008. Whole euthanized fish or organ samples (spleen, kidney and heart or brain) of 30 fish were sent to the Finnish Food Safety Authority Evira in Helsinki (the national reference laboratory) for virus isolation. Company A was sampled 3 times and samples were taken from a total of 66 fish pooled into 8 organ samples (Table 2). Company B was sampled 20 times from 9 different farming sites; altogether, 552 fish pooled into 57 organ samples were examined (Table 2). According to the legislation, fish farmers are obliged to inform authorities if they suspect notifiable diseases in their fish populations (2006/88/EC). Samples in connection with suspicion of disease were taken 4 times.

\section{Virus isolation}

Tissue samples of brain, anterior kidney and spleen were processed according to standard virological procedures described by Raja-Halli et al. (2006). The supernatant of the homogenized and centrifuged $(4000 \times g, 15 \mathrm{~min})$ samples was collected for immediate inoculation into 24-well tissue culture plates (Nunc) with monolayer cell cultures of bluegill fry fibroblasts (BF-2) or epithelioma papulosum cyprinid (EPC) epithelial cells (Olesen \& Vestergård Jørgensen 1992). In surveillance Pro- grammes $1-3$, the samples were inoculated in BF-2 and EPC cells no later than $24 \mathrm{~h}$ post-euthanasia. Virus isolation in Programme 4 was performed as in Programmes 1-3, with the exception that according to the instructions given in Commission Decision 2001/183/EC (EC 2001), the maximum time between euthanasia of the fish and inoculation of samples into cell culture was $48 \mathrm{~h}$. All samples in all programmes were incubated in 2 passages for at least $14 \mathrm{~d}$ in total.

\section{qRT-PCR for examining the presence of VHSV from tissue suspensions}

qRT-PCR reactions were performed from samples in Programmes 1-3 according to Chico et al. (2006). A volume of $1 \mathrm{ml}$ of the same organ suspension that was used for virus isolation was frozen at $-80^{\circ} \mathrm{C}$ for qRT-PCR. RNA extraction was carried out using an RNeasy Mini Kit (Qiagen) starting with $200 \mu$ suspension according to the manufacturer's protocol, and the final elution volume was $32 \mu \mathrm{l}$.

RT-PCR was performed with a QuantiTect Probe RT-PCR Kit (Qiagen) according to the manufacturer's instructions. Five microliters of extracted RNA was used in a $25 \mu$ reaction volume. The final concentrations of the primers and the probe were 300 and $100 \mathrm{nM}$, respectively. The $\mathrm{RT}$ reaction profile was: $30 \mathrm{~min}$ at $50^{\circ} \mathrm{C}, 15 \mathrm{~min}$ at $95^{\circ} \mathrm{C}$, followed by 50 cycles of $15 \mathrm{~s}$ at $95^{\circ} \mathrm{C}$ and $1 \mathrm{~min}$ at $60^{\circ} \mathrm{C}$.

The primers and the probe for the qRT-PCR were manufactured (MedProbe) according to the VHSV sequence from GenBank accession no. D00687 after Chico et al. (2006). The probe was 5-end labelled with the fluorescent dye FAM and 3-end labelled with the fluorescent dye TAMRA (Table 3).

\section{Sequencing of isolated VHSV strains}

To confirm the presence of VHSV and to determine the genotype of the strain, the complete sequence of the glycoprotein $(\mathrm{G})$ gene of 3 rainbow trout VHSV isolates from different surveillance programmes was amplified in 4 different $\mathrm{RT}$-PCR reactions, and the amplicons were sequenced with primers used in the PCRs. RT-PCR amplifications were performed as described by Raja-Halli et al. (2006). Primer sequences (Table 3) targeting VHSV G, matrix (M) and nonstructural (NV) gene regions were based on the published genome of VHSV strain Fi13 (Schütze et al. 1999). 


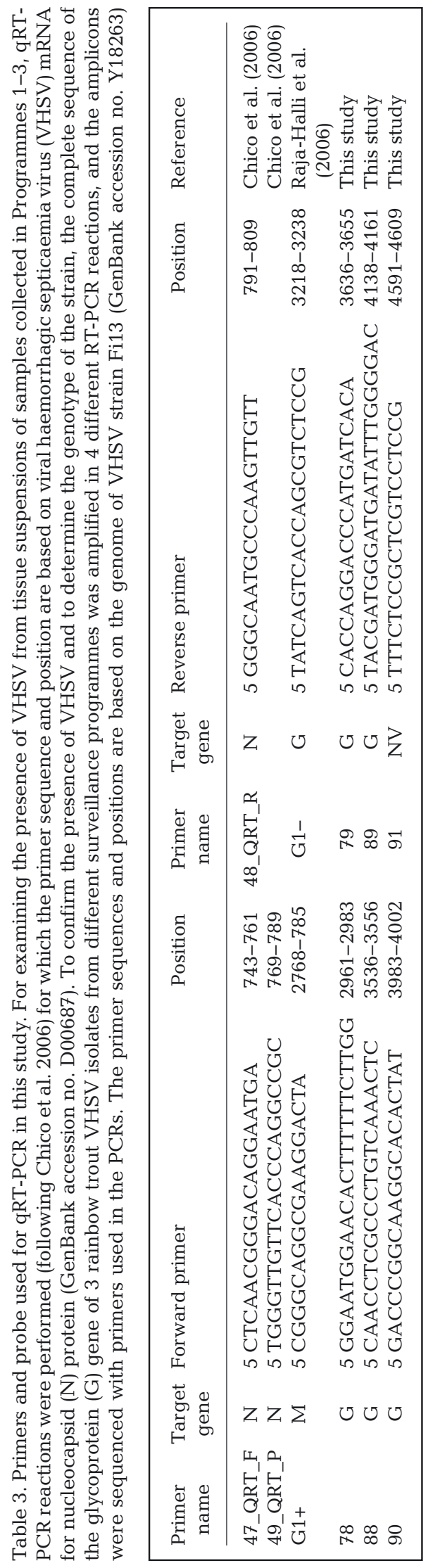

Sequencing reactions were performed using Big Dye v.3.1 chemistry (Applied Biosystems), and the reactions were run on an ABI3100 Avant genetic analyser. For each sample, the individual PCR sequences were edited and assembled into contigs by using Lasergene SeqMan Pro, v. 8.0.2 (DNASTAR). The GenBank accession numbers for the sequences reported herein are MF176925-MF176927.

The assembled sequences from this study were aligned with the $\mathrm{G}$ gene sequences of selected Finnish and other VHSV isolates belonging to genotypes I-IV (GenBank accession numbers AM086354, AM086358, AM086365, AM086379, AM086383, Z93 412, HQ112234, GQ504013, AY546582, AB179621), and the percentage identities between paired nucleotide sequences were calculated using the programme Megalign (DNASTAR).

\section{Detection of antibodies against VHSV from trout serum with an indirect ELISA}

Testing serum for antibodies against VHSV can reveal infected fish populations that could have been missed when testing organ samples for virus at an earlier point in time. Collected blood samples were centrifuged $(3000 \times g, 15 \mathrm{~min})$ to obtain serum. The serum samples were heat inactivated for $30 \mathrm{~min}$ at $45^{\circ} \mathrm{C}$ (Olesen et al. 1991) and frozen $\left(-80^{\circ} \mathrm{C}\right)$ until examination. The serum samples were tested for the presence of VHSV antibodies by an indirect ELISA method (diagnostic specificity, Sp: 1.0; diagnostic sensitivity, Se: 0.92) (Olesen et al. 1991). To verify the ELISA results, a set of samples was tested in parallel in another laboratory at Ploufragan/Plouzané, Unité de pathologie virale des poisons (Afssa). The samples were tested with the same ELISA method and with a serum neutralisation test (Sp 1.0 and Se 0.6) (Olesen \& Vestergård Jørgensen 1986, Olesen et al. 1991, Castric et al. 2009). The received results were classified into positive/negative and were consistent with our results.

\section{Statistical analysis}

The effectiveness of different surveillance programmes in detecting VHSV infections was estimated using a binomial generalized linear model (GLM) (logit link):

$\operatorname{Logit}(Y)=a($ Programme1 $)+b($ Programme $)+$ $c($ Programme 3$)+d($ Programme 4$)+e T+f T^{2}$ 
where $Y=$ a positive detection of VHSV, $T=$ temperature $\left({ }^{\circ} \mathrm{C}\right)$ and $a, b, c, d$, e and $f=$ coefficients. Programme 4 was treated as a reference category and was the intercept of the estimated model. An omnibus test was used to determine whether the model was better than the intercept-only model. A model without temperature as a covariate was estimated to assess whether the inclusion of temperature changed the relative efficiencies of the programmes. Probabilities of detection were calculated from a logistic model in the usual way: Probability of detection =

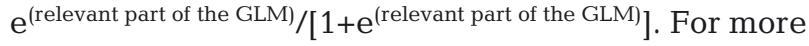
information, see Dohoo et al. (2009). Statistical analyses were performed using IBM SPSS Statistics version 22 .

The modified qRT-PCR test was compared with virus isolation by cell culture (gold standard test for detecting VHSV) in order to calculate the Se and Sp with Epitools (Sergeant 2016). The threshold cycle $\left(\mathrm{C}_{\mathrm{t}}\right)$ cut-off was estimated using 2-graph receiver operating characteristic (TG-ROC) curves (Caraguel et al. 2011) with Epitools (Sergeant 2016).

\section{RESULTS}

\section{Detection of VHSV infection in different programmes}

Programme 1. VHSV was detected on $75 \%$ of the sampling occasions (Table 2). On 3 occasions, other infectious agents such as Aeromonas salmonicida sp. salmonicida, Tetracapsuloides bryosalmonae and Flavobacterium psychrophilum were diagnosed as the cause of the signs of disease. On 1 occasion, a mixed infection of VHS and F. psychrophilum was detected. On 9 sampling occasions, qRT-PCR was run from the same organ suspensions that were used for virus isolation, and the results were consistent with the virus isolation results (Table 2).

Programme 2. Population AP2, imported from Denmark in June 2006, was found to be infected by infectious pancreatic necrosis virus (IPN) at the time of import. IPN virus was neutralized from the samples with an anti-IPN serum to rule out a possible latent VHSV infection according to the OIE instructions (OIE 2017). VHSV was not detected in the imported fish at the time of arrival. Mortality in population AP2 caused by bacterial infection with Yersinia ruckeri was recorded in June 2007, but no evidence of the presence of VHSV was found either by virus isolation or qRT-PCR. Population BP2 was negative throughout the entire surveillance programme. In population
BP3, VHSV was recorded twice. In June 2007, qRTPCR gave for the first time a positive result for the presence of VHSV in the population, 6 mo after the beginning of the surveillance. VHSV was not isolated from these samples and no clinical signs of disease were noted by that time. In December 2007, at the time of slaughter, population BP3 experienced a clinical outbreak of VHS, and 4 out of 6 pools were positive for VHSV according to both virus isolation and qRT-PCR tests (Table 2).

Programme 3. VHSV was isolated again in BP4 in May 2008, about 1 yr after the first clinical infection when the surveillance started (Table 2). Population $\mathrm{BP} 4 \mathrm{E}$ was also infected by that time and clinical signs of VHS were recorded. The second VHSV-positive population, BP5, and its neighbouring population, BP5E, were sampled twice after the first outbreak of clinical VHS in June 2007 (Table 2). No virus was detected and no clinical signs of infectious disease were noted in BP5 after June 2007. Mortality caused by VHSV was recorded in population BP5E in December 2007, 4 mo after the surveillance started. In BP5E, 1 out of 40 pools were positive according to both virus isolation and qRT-PCR. VHSV was not detected in the control fish.

Programme 4. VHSV was not detected in samples from Company A, although in 2 of 3 inspected populations, clinical symptoms of an infectious disease were reported to be present (Table 2). These symptoms were explained by $Y$. ruckeri infection, IPNV infection and proliferative kidney disease (PKD). VHSV was detected once in samples from Company B, but no information on whether these fish had clinical symptoms was available. Clinical symptoms were reported in 2 other screened populations, but in these cases, no VHS infection was detected and no additional sampling was performed to explain the symptoms. When the results for Companies A and B were combined, VHSV was detected on $4 \%$ of the sampling occasions (Table 2).

\section{Efficiency of the sampling programmes in detecting VHSV by virus isolation}

Both models (with and without temperature as a covariate) indicated that Programmes 1 and 3 gave positive results statistically significantly more often than Programme 4 (Table 4), whereas Programme 2 did not differ statistically significantly from Programme 4. This indicated that the probability of detection in these 2 surveillance programmes ( 2 and 4 ) was essentially very similar (Fig. 2). Depending on the 
Table 4. Detection of VHSV by different surveillance programmes, estimated using a binomial generalized linear model (GLM), where temperature was included or excluded as a covariate. The estimated coefficient and the standard error (SE) are given, as well as Wald test statistics and the corresponding probability estimate that $H_{0}$ (coefficient is equal to 0 ) would be true

\begin{tabular}{|lrrc|}
\hline & Coef. (SE) & Wald & $\mathrm{p}$ \\
\hline Model with temperature & & & \\
Programme 1 & $5.19(1.14)$ & 20.83 & 0.000 \\
Programme 2 & $0.76(1.44)$ & 0.27 & 0.600 \\
Programme 3 & $2.87(1.22)$ & 5.52 & 0.019 \\
Programme 4 (intercept) & $-7.73(2.58)$ & 8.97 & 0.003 \\
$T$ & $1.41(0.64)$ & 4.89 & 0.027 \\
$T^{2}$ & $-0.09(0.04)$ & 6.07 & 0.014 \\
Model without temperature & & & \\
Programme 1 & $4.19(1.22)$ & 11.78 & 0.001 \\
Programme 2 & $0.79(1.47)$ & 0.29 & 0.590 \\
Programme 3 & $2.40(1.16)$ & 4.27 & 0.039 \\
Programme 4 (intercept) & $-3.09(1.02)$ & 9.14 & 0.003 \\
\hline
\end{tabular}

model, Programme 1 gave a 13.7-17.4 times higher probability of detection and Programme 3 a $7.7-8.3$ times higher probability of detection than Programme 4 (the official EU standard) (Fig. 2).

As can be seen from Table 4, the standard errors of the coefficients were slightly higher in the model that did not take into account the temperature effect on VHSV detection. However, since the parameter uncertainty of the covariates ( $T$ and $T^{2}$ ) also increased the confidence intervals of the probability of detection, the benefit of the more complicated model appeared to be small in this case (Table 4). Nonetheless, temperature seemed to have a statistically significant impact on model performance.

\section{Detection of VHSV antibodies in screened populations}

Antibodies against VHSV were detected in only 4 serum samples out of 120 tested in Programme 2 (Table 2). In Programme 3, populations BP4, BP4E, BP5 and BP5E tested positive for VHSV antibodies on several occasions (Table 2).

\section{Correspondence of diagnostic methods on each sampling occasion}

The $\mathrm{C}_{\mathrm{t}}$ cut-off for the qRT-PCR method that was used was set at 36. qRT-PCR analysis for separate sampling occasions (Programmes 1-3) corresponded well with

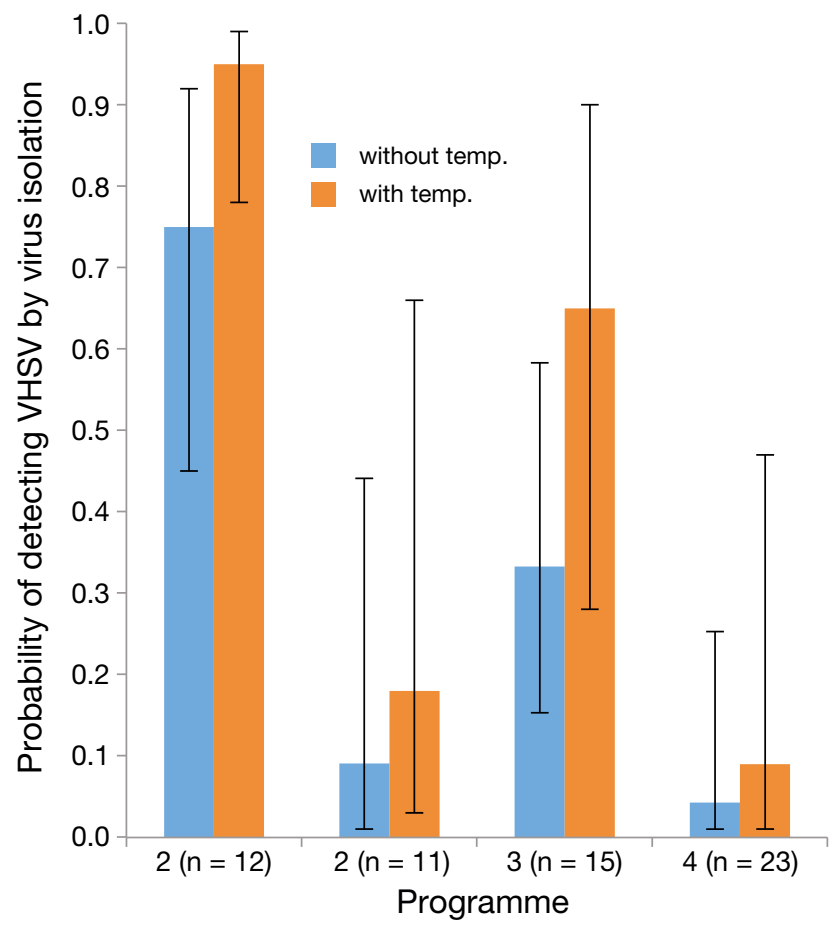

Fig. 2. Probability of detecting viral haemorrhagic septicaemia virus (VHSV) by virus isolation in different surveillance programmes (see Table 1) estimated using a generalized linear model (GLM) that included ('with temp.') or excluded ('without temp.') temperature as a covariate. Marginal means were adjusted to $10.0^{\circ} \mathrm{C}$ if temperature was applied in the GLM. Error bars represent the $95 \%$ confidence interval for the mean. The number of samples in each programme is given in parentheses

the virus isolation results, as the kappa value was 0.877 . The sensitivity and specificity of qRT-PCR was 1 and 0.959 , respectively. The positive likelihood ratio was 24 and the negative likelihood ratio 0 . Confidence limits were $0.92-1.00$ for sensitivity and $0.92-0.98$ for specificity.

\section{Sequencing of isolated VHS viruses}

The G gene of 3 rainbow trout VHSV isolates (Fi08.50RT, Fi06.59RT and Fi06.108RT) originating from different surveillance programmes in this study was sequenced and compared with the G gene sequences of some Finnish and other VHSV isolates belonging to genotypes I-IV (Table 5, Fig. S1 in the Supplement at www.int-res.com/articles/suppl/d126 p111_supp.pdf). Pairwise sequence comparisons showed that the rainbow trout isolates of this study were most closely related to the Finnish rainbow trout genotype I isolates from Åland, isolated during 
Table 5. Reference viral haemorrhagic septicaemia virus (VHSV) isolates used in the sequence comparisons

\begin{tabular}{|lcccc|}
\hline VHSV isolate & Host & $\begin{array}{c}\text { Location and } \\
\text { year of isolation }\end{array}$ & $\begin{array}{c}\text { Genotype } \\
\text { GenBank } \\
\text { acc. no. }\end{array}$ \\
\hline Fi01a_b.00 & Rainbow trout & Finland 2000 & Id & AM086354 \\
FiA02a.01 & Rainbow trout & Finland 2001 & Id & AM086358 \\
FiA03.02 & Rainbow trout & Finland 2002 & Id & AM086365 \\
FiA03.03 & Rainbow trout & Finland 2003 & Id & AM86379 \\
Fi19.04 & Rainbow trout & Finland 2004 & Id & AM086383 \\
Hededam & Rainbow trout & Denmark 1972 & I & Z93412 \\
FI-ka366-04 & Herring & Finland 2004 & II & HQ112234 \\
FI-Lamprey- & Lamprey & Finland 2003 & II & GQ504013 \\
743.03 & Herring & Skagerrak 1997 & III & AY546582 \\
DK-4p168 & Japanese flounder & Japan 2000 & IV & AB179621 \\
KRRV9822 & & & & \\
\hline
\end{tabular}

2000-2004 (Raja-Halli et al. 2006). The nucleotide (nt) identity between these isolates was $99.7-99.9 \%$, whereas the nt identity between Finnish lamprey and herring VHSV isolates belonging to genotype II (Gadd et al. 2010, 2011) and isolates from this study was only approximately $89 \%$ (Table S1 in the Supplement). The $\mathrm{G}$ gene sequence identity between VHSV isolates from this study and VHSV isolates belonging to genotypes III and IV was approximately 91 and $86 \%$, respectively. These results indicate that the current VHSV isolates belonged to genotype I and confirm that VHS infection was still present in Åland during the time of this study.

\section{DISCUSSION}

Syndromic surveillance (Programme 1) was the most reliable means to screen for the presence of VHSV, being up to 17 times more effective than active surveillance in Programme 4 (Table 4). This result indicates that active surveillance only using methods to detect virus, although regarded as sufficient to show infection in a zone, is not a reliable tool to reveal whether a single population is or has been infected by VHSV. It is notable that Programme 3, with sampling after a clinical VHS outbreak, performed almost as well as Programme 1, while the other 2 sampling programmes ( 2 and 4 ) performed less efficiently. In practice, an active surveillance scheme that is performed after a confirmed clinical VHS outbreak would not be a sensible strategy to identify VHSV-infected farms, as they will have already been found. In contrast, syndromic surveillance outperformed active surveillance programmes and has clear practical value.

Both virus isolation in cell culture and qRT-PCR are reliable tests to detect VHSV when there is an acute
VHSV infection at the time of sampling, but effective early warning systems are required to detect signs of the disease. qRT-PCR is a rapid and reliable test to confirm or rule out the presence of VHSV in organ suspension when clinical signs have given reason to suspect infection. qRT-PCR is also reported to be valuable in finding asymptomatic fish carrying VHSV (Hope et al. 2010). In our study, qRTPCR detected a possible carrier on 1 occasion when virus isolation in cell culture failed. This was a situation in spring 2007 when the water temperature was close to $15^{\circ} \mathrm{C}$ and rising. It is possible that this population had just been infected and clinical signs of VHS had not appeared before the water temperature rose above $15^{\circ} \mathrm{C}$. We have noticed that outbreaks due to VHSV Id do not occur and the virus cannot be isolated at temperatures higher than $15^{\circ} \mathrm{C}$. Serum samples that were collected on the same occasion did not reveal any antibodies against VHSV, also suggesting an early infection. Our suspicion concerning the carrier state was confirmed the next autumn when the water temperature dropped below $15^{\circ} \mathrm{C}$ and the fish in this population experienced a clinical disease outbreak. Serum samples taken at this time revealed only 1 positive sample out of 15 tested. This suggests a new infection and indicates that the virus infection did not have time to spread in the population before water temperature rose above $15^{\circ} \mathrm{C}$ during the previous spring.

qRT-PCR is valuable when screening for a particular virus, e.g. in wild fish, and where a positive signal does not lead to legal actions against the business owner. qRT-PCR could also be used as the primary diagnostic screening test for fish farms, but a positive result should be confirmed by other methods such as antibody testing. ELISA or plaque neutralisation tests have been reported to be good tools to screen for antibodies against VHSV in Europe and the USA (FregenedaGrandes \& Olesen 2007, Fregeneda-Grandes et al. 2009, Schyth et al. 2012, Millard et al. 2014, Wilson et al. 2014). Our study also proved ELISA to be a useful method for screening, since VHSV infection could be detected several months after a clinical disease outbreak occurred. However, the results were only easy to interpret if there had been a clear clinical outbreak no more than 1 yr previously in the population.

The water temperature in the sea area in Finland varies from slightly above $0^{\circ} \mathrm{C}$ in winter to often above $20^{\circ} \mathrm{C}$ in summer. In autumn, the water temper- 
ature drops below $15^{\circ} \mathrm{C}$ in late September, and ice usually covers the farming sites from December to late April. This ice layer makes inspection and sampling impossible for several months. When the ice layer melts in spring, the water temperature often rises above $15^{\circ} \mathrm{C}$ within $2-3 \mathrm{mo}$, varying from year to year. This gives a short time window for the authorities to visit the farms, which are scattered around thousands of small, difficult to reach islands. Additionally, the manpower of the authorities is restricted, as they have duties covering all animal groups and usually limited experiences of fish diseases.

Early detection of VHS is essential for successful disease eradication. Virus infections are easily spread between farms in the same area due to daily management. Routine clinical inspections performed by skilled fish health specialists have also been noted as essential in the surveillance of freedom from VHS in Norwegian marine salmon farms (Lyngstad et al. 2016). Our study supports the Norwegian report by demonstrating that more frequent monitoring for clinical signs of VHS outperforms active surveillance. There are no fish health services offering routine clinical inspection or sampling services for the fish farms in the study area. The farming sites are difficult to reach and shipping of samples by the farmers themselves for testing of diseases is complicated, as the logistics involved in transferring samples between the study area and the laboratory are poor. Farmers only sent samples when high mortalities were seen; mild signs of disease were often not confirmed. VHSV Id was reported to cause $40 \%$ mortalities in an infection trial (Raja-Halli et al. 2006), but we have rarely seen such high mortalities in the study area (authors' unpubl. data). Mortalities ranging from 10 up to $50 \%$ have only been seen under stressful conditions, such as the transportation of infected populations between farming sites.

The good results of syndromic surveillance in Programme 1 could have been because the staff of the fish farm already had 6 yr of experience with VHS and good skills in detecting abnormalities in a fish population indicating a disease outbreak in the early stages of infection. The finding that temperature affected the performance of the programmes might be associated with this; fish farmers found the occurrence of clinical cases at certain temperatures to be typical of the disease. The staff of the study fish farms were also motivated to participate in this surveillance, and new means of transportation of samples to the laboratory were found, which was considered to be vitally important for this field study. The populations were also carefully observed at the time of sampling for screening in Programmes 2 and 3 , but only the farmers were able to follow up their fish populations daily. Another explanation for the good results in Programme 1 could be that this type of screening finds infections in their early stages, when it is easier to detect the virus because of the higher viral amounts in the samples. Sandlund et al. (2014) reported that gills are useful target organs in screening chronic or sub-acute VHSV infections. Therefore, it could be argued that Programme 1 would not differ as much from the other programmes if gills had also been tested in the other programmes. However, gills were used on 2 occasions in parallel with the other organ samples of the same fish in this study without gaining any new information (P. Vennerström unpubl. data). Additionally, it could be argued that Programme 4 would have been more efficient if farmers had reported their suspicions according to the legislation. It is doubtful that VHSV would have been diagnosed to the same extent without the separate Programme 1. The successful eradication of VHSV in 2 other areas on the south coast of Finland in 2001 and 2003 (reinfection 2008) could be explained by the early detection and rapid eradication of affected farming sites, which is vital for the eradication of and subsequent freedom from disease. Farmers contacted the authorities immediately when they noticed suspicious disease signs. Eradication was performed without delay and in good cooperation between farmers and authorities. In Åland, this cooperation was not as successful at the beginning and VHSV rapidly spread between farming sites, and stamping out the disease was not economically justified. We believe that this study managed to improve the screening of VHSV and biosecurity measures in this area. According to the official disease surveillance in the restriction area in Åland, the number of VHS-positive samplings has followed a decreasing trend (ICES 2014), which indicates a lower infection pressure in the area. VHSV has not been isolated in the study area since 2012 (Finnish Food Safety Authority 2016).

\section{CONCLUSION}

Syndromic surveillance (based on the observation of clinical disease signs by fish farmers) is more sensitive than active surveillance when detecting VHSV infections on fish farms. Active surveillance (Programmes 2, 3 and 4) did not yield information that would have been needed for preparing eradication plans in the VHS eradication zone of Åland. 
Real-time RT-PCR was at least as reliable as virus isolation in cell culture to detect infection in this study, but serology proved to be a useful test to determine whether a fish population had been infected with VHSV. However, the antibody levels are very low in mild disease outbreaks or if the infection has occurred several months earlier. Therefore, the use of this antibody test in screening for VHSV in disease-free areas is not reliable without affirmation of the test results with another test, such as virus isolation or PCR. On the other hand, it is a useful additional tool in VHSV eradication for screening populations during the follow-up period, before declaring an area free of infection.

Acknowledgements. This work was funded by the Finnish Ministry of Agriculture and Forestry, Dno 4876/501/2005, project 310159. We thank Niels Jørgen Olesen and Jeannette Castric for their help with the serological method and valuable expertise. We thank Pia Vilen for designing the map in Fig. 1 and Satu Viljamaa-Dirks for critical reading of the manuscript. We also thank Lars Lönnström for his help on the fish farms.

\section{LITERATURE CITED}

Ammayappan A, Vakharia VN (2009) Molecular characterization of the Great Lakes viral hemorrhagic septicemia virus (VHSV) isolate from USA. Virol J 6:171

Bain MB, Cornwell ER, Hope KM, Eckerlin GE and others (2010) Distribution of an invasive aquatic pathogen (viral hemorrhagic septicemia virus) in the Great Lakes and its relationship to shipping. PLOS ONE 5:e10156

Caraguel CG, Stryhn H, Gagne N, Dohoo IR, Hammell KL (2011) Selection of a cutoff value for real-time polymerase chain reaction results to fit a diagnostic purpose: analytical and epidemiologic approaches. J Vet Diagn Invest 23:2-15

Castric J, Quentel C, Cabon J, Lamour F, Olesen NJ (2009) Results from an inter-laboratory proficiency test on detection of antibodies against VHSV and IHNV in rainbow trout. In: 13th Annual Meeting of the National Reference Laboratories for Fish Disease, Copenhagen, Denmark, May 26-28, 2009, p 28-29

Chico V, Gomez N, Estepa A, Perez L (2006) Rapid detection and quantitation of viral hemorrhagic septicemia virus in experimentally challenged rainbow trout by real-time RT-PCR. J Virol Methods 132:154-159

Dale OB, Ørpetveit I, Lyngstad TM, Kahns S, Skall HF, Olesen NJ, Dannevig BH (2009) Outbreak of viral haemorrhagic septicaemia (VHS) in seawater-farmed rainbow trout in Norway caused by VHS virus Genotype III. Dis Aquat Org 85:93-103

Dohoo I, Martin W, Styhn H (2009) Veterinary epidemiologic research, 2nd edn. VER Inc., Charlottetown, PEI

EC (European Commission) (2001) 2001/183/EC: Commission Decision of 22 February 2001 laying down the sampling plans and diagnostic methods for the detection and confirmation of certain fish diseases and repealing Decision 92/532/EEC. http://eur-lex.europa.eu/legal-
content/en/ALL/?uri=CELEX:32001D0183

EC (2003) 2003/634/EC: Commission Decision of 28 August 2003 approving programmes for the purpose of obtaining the status of approved zones and of approved farms in non-approved zones with regard to viral haemorrhagic septicaemia (VHS) and infectious haematopoietic necrosis (IHN) in fish. http://eur-lex.europa.eu/legal-content/ en/ALL/?uri=CELEX:32003D0634

Einer-Jensen K, Ahrens P, Lorenzen N (2005) Parallel phylogenetic analyses using the N, G or Nv gene from a fixed group of VHSV isolates reveal the same overall genetic typing. Dis Aquat Org 67:39-45

Elsayed E, Faisal M, Thomas M, Whelan G, Batts W, Winton $J$ (2006) Isolation of viral haemorrhagic septicaemia virus from muskellunge, Esox masquinongy (Mitchill), in Lake St Clair, Michigan, USA reveals a new sublineage of the North American genotype. J Fish Dis 29:611-619

*Emmenegger EJ, Moon CH, Hershberger PK, Kurath G (2013) Virulence of viral hemorrhagic septicemia virus (VHSV) genotypes Ia, IVa, IVb, and IVc in five fish species. Dis Aquat Org 107:99-111

* Finnish Food Safety Authority (2016) Animal diseases in Finland 2015. Evira Publication Series 5:23-24

*Fregeneda-Grandes JM, Olesen NJ (2007) Detection of rainbow trout antibodies against viral haemorrhagic septicaemia virus (VHSV) by neutralisation test is highly dependent on the virus isolate used. Dis Aquat Org 74: $151-158$

Fregeneda-Grandes JM, Skall HF, Olesen NJ (2009) Antibody response of rainbow trout with single or double infections involving viral haemorrhagic septicaemia virus and infectious haematopoietic necrosis virus. Dis Aquat Org 83:23-29

Gadd T, Jakava-Viljanen M, Einer-Jensen K, Ariel E, Koski P, Sihvonen L (2010) Viral haemorrhagic septicaemia virus (VHSV) genotype II isolated from European river lamprey Lampetra fluviatilis in Finland during surveillance from 1999 to 2008. Dis Aquat Org 88:189-198

Gadd T, Jakava-Viljanen M, Tapiovaara H, Koski P, Sihvonen L (2011) Epidemiological aspects of viral haemorrhagic septicaemia virus genotype II isolated from Baltic herring, Clupea harengus membras L. J Fish Dis 34:517-529

Garver KA, Traxler GS, Hawley LM, Richard J, Ross JP, Lovy J (2013) Molecular epidemiology of viral haemorrhagic septicaemia virus (VHSV) in British Columbia, Canada, reveals transmission from wild to farmed fish. Dis Aquat Org 104:93-104

Groocock GH, Getchell RG, Wooster GA, Britt KL and others (2007) Detection of viral hemorrhagic septicemia in round gobies in New York State (USA) waters of Lake Ontario and the St. Lawrence River. Dis Aquat Org 76:187-192

*Hedrick RP, Batts WN, Yun S, Traxler GS, Kaufman J, Winton JR (2003) Host and geographic range extensions of the North American strain of viral hemorrhagic septicemia virus. Dis Aquat Org 55:211-220

*Hope KM, Casey RN, Groocock GH, Getchell RG, Bowser PR, Casey JW (2010) Comparison of quantitative RT-PCR with cell culture to detect viral hemorrhagic septicemia virus (VHSV) IVb infections in the Great Lakes. J Aquat Anim Health 22:50-61

ICES (International Council for the Exploration of the Sea) (2014) Second Interim Report of the Working Group on Pathology and Diseases of Marine Organisms (WGPD MO), 25-28 February 2014. ICES CM 2014/SSGHIE:02. ICES, Copenhagen 
Isshiki T, Nishizawa T, Kobayashi T, Nagano T, Miyazaki T (2001) An outbreak of VHSV (viral hemorrhagic septicemia virus) infection in farmed Japanese flounder Paralichthys olivaceus in Japan. Dis Aquat Org 47:87-99

Ito T, Olesen NJ (2013) Susceptibility of various Japanese freshwater fish species to an isolate of viral haemorrhagic septicaemia virus (VHSV) genotype IVb. Dis Aquat Org 107:1-8

Kim R, Faisal M (2010) Experimental studies confirm the wide host range of the Great Lakes viral haemorrhagic septicaemia virus genotype IVb. J Fish Dis 33:83-88

Lehtiniemi M, Lehtinen S (2016) Aland Sea (F64) Northwestern Baltic. METABASE Explorer - The Marine Ecological Time Series database. www.st.nmfs.noaa.gov/ copepod/time-series/fi-30102-003/

Lumsden JS, Morrison B, Yason C, Russell S and others (2007) Mortality event in freshwater drum Aplodinotus grunniens from Lake Ontario, Canada, associated with viral haemorrhagic septicemia virus, type IV. Dis Aquat Org 76:99-111

Lyngstad TM, Hellberg H, Viljugrein H, Bang Jensen B, Brun E, Sergeant E, Tavornpanich S (2016) Routine clinical inspections in Norwegian marine salmonid sites: a key role in surveillance for freedom from pathogenic viral haemorrhagic septicaemia (VHS). Prev Vet Med 124:85-95

Meyers TR, Short S, Lipson K (1999) Isolation of the North American strain of viral hemorrhagic septicemia virus (VHSV) associated with epizootic mortality in two new host species of Alaskan marine fish. Dis Aquat Org 38: 81-86

Millard EV, Brenden TO, LaPatra SE, Marcquenski S, Faisal M (2014) Detection of viral hemorrhagic septicemia virus$\mathrm{IVb}$ antibodies in sera of muskellunge Esox masquinongy using competitive ELISA. Dis Aquat Org 108:187-199

OIE (World Organisation for Animal Health) (2017) Manual of diagnostic tests for aquatic animals. www.oie.int/ international-standard-setting/aquatic-manual/accessonline/

Olesen NJ, Vestergård Jørgensen PE (1986) Detection of neutralizing antibody to Egtved virus in rainbow trout (Salmo gairdneri) by plaque neutralization test with complement addition. J Appl Ichthyol 2:33-41

Olesen NJ, Vestergård Jørgensen PE (1992) Comparative susceptibility of three fish cell lines to Egtved virus, the virus of viral haemorrhagic septicaemia (VHS). Dis Aquat Org 12:235-237

Olesen NJ, Lorenzen N, Jørgensen PEV (1991) Detection of rainbow trout antibody to Egtved virus by enzymelinked immunosorbent assay (ELISA), immunofluorescence (IF), and plaque neutralization tests (50\% PNT). Dis Aquat Org 10:31-38

Pierce LR, Stepien CA (2012) Evolution and biogeography of an emerging quasispecies: diversity patterns of the fish Viral Hemorrhagic Septicemia virus (VHSv). Mol Phylogenet Evol 63:327-341

Raja-Halli M, Vehmas TK, Rimaila-Pärnänen E, Sainmaa S, Skall HF, Olesen NJ, Tapiovaara H (2006) Viral haemorrhagic septicaemia (VHS) outbreaks in Finnish rainbow trout farms. Dis Aquat Org 72:201-211

Ross K, McCarthy U, Huntly PJ, Wood BP and others (1995) An outbreak of viral haemorrhagic septicaemia (VHS) in turbot (Scophthalmus maximus) in Scotland. Bull Eur Assoc Fish Pathol 14:213-214

Sandlund N, Gjerset B, Bergh O, Modahl I, Olesen NJ, Johansen R (2014) Screening for viral hemorrhagic septicemia virus in marine fish along the Norwegian coastal line. PLOS ONE 9:e108529

Schönherz AA, Lorenzen N, Einer-Jensen K (2013) Inter-species transmission of viral hemorrhagic septicemia virus (VHSV) from turbot (Scophthalmus maximus) to rainbow trout (Onchorhynchus [sic] mykiss). J Gen Virol 94: 869-875

Schütze H, Mundt E, Mettenleiter TC (1999) Complete genomic sequence of viral hemorrhagic septicemia virus, a fish rhabdovirus. Virus Genes 19:59-65

Schyth BD, Ariel E, Korsholm H, Olesen NJ (2012) Diagnostic capacity for viral haemorrhagic septicaemia virus (VHSV) infection in rainbow trout (Oncorhynchus mykiss) is greatly increased by combining viral isolation with specific antibody detection. Fish Shellfish Immunol 32: 593-597

Sergeant E (2016) Epitools epidemiological calculators. AusVet Animal Health Services and Australian Biosecurity Cooperative Research Centre for Emerging Infectious Disease. http://epitools.ausvet.com.au

Skall HF, Olesen NJ, Mellergaard S (2005a) Viral haemorrhagic septicaemia virus in marine fish and its implications for fish farming - a review. J Fish Dis 28:509-529

Skall HF, Olesen NJ, Mellergaard S (2005b) Prevalence of viral haemorrhagic septicaemia virus in Danish marine fishes and its occurrence in new host species. Dis Aquat Org 66:145-151

Smail DA (1999) Viral hemorrhagic septicaemia. In: Woo PTK, Bruno DW (eds) Fish diseases and disorders, Vol 3: viral, bacterial and fungal infections. CAB International, New York, NY, p 123-147

Smail DA, Snow M (2011) Viral hemorrhagic septicaemia. In: Woo PTK, Bruno DW (eds) Fish diseases and disorders, Vol 3: viral, bacterial and fungal infections, 2nd edn. CAB International, Wallingford, p 110-142

Snow M, Cunningham CO, Melvin WT, Kurath G (1999) Analysis of the nucleoprotein gene identifies distinct lineages of viral haemorrhagic septicaemia virus within the European marine environment. Virus Res 63:35-44

Walker PJ, Benmansour A, Dietzgen R, Fang RX and others (2000) Family Rhabdoviridae. In: Van Regenmortel MHV, Fauquet CM, Bishop DHL and others (eds) Virus taxonomy. Classification and nomenclature of viruses. Seventh Report of the International Commitee on Taxonomy of Viruses. Academic Press, San Diego, CA, and London, p 563-583

Wilson A, Goldberg T, Marcquenski S, Olson W and others (2014) Development and evaluation of a blocking enzyme-linked immunosorbent assay and virus neutralization assay to detect antibodies to viral hemorrhagic septicemia virus. Clin Vaccine Immunol 21:435-442

Submitted: January 3, 2017; Accepted: July 27, 2017

Proofs received from author(s): October 2, 2017
Editorial responsibility: Lori Gustafson,

Fort Collins, Colorado, USA 